\title{
A mini review highlights on the application of nano-materials for Kidney disease: A key development in Medicinal therapy
}

\author{
Ateeq Rahman ${ }^{1 *}$, Daniel Likius ${ }^{1}$, Veikko Uahengo ${ }^{1}$ and Syed Iqbaluddin ${ }^{2}$ \\ ${ }^{1}$ Faculty of Science, Department of Chemistry and Biochemistry, University of Namibia, Windhoek, Post Bag 13301-Namibia \\ ${ }^{2}$ Department of Pharmacy, Mafraq Hospital, Baniyas,Abu Dhabi, P.O. Box- 2951, United Arab Emirates
}

\begin{abstract}
Nanoparticles have been one of the emerging tools in medical field as a technology well-suited for the diagnosis and treatment of various diseases. They have been heralded as efficacious owing to both in terms of improved therapeutic efficacy as well as reduction of treatment side effects in some cases. Various nanomaterials have been developed which can be tagged with targeting moieties, and with drug delivery and imaging capability or combination of both as theranostic agent.

Biotechnology to a large extent relies greatly on biomolecules such as proteins and DNA. Research in the field of bio technology will undeniably profit with the initiation of chemical and materials synthesis (e.g. multifunctional nanoparticle systems) that allows fusion of these biomolecules to nanostructured inorganic and organic materials. These nanomaterials have been thoroughly investigated for treatment and detection of various pathological conditions. This mini review highlights, the shape, size of nanoparticles to demonstrate the current research and applications of nanoparticles in the treatment of kidney diseases.
\end{abstract}

\section{Introduction}

Chronic kidney disease (CKD) is characterized by progressive loss of kidney function which decreases the ability of the body to eliminate soluble waste resulting in the gathering of "uremictoxins" [1]. It is now well documented that CKD is an inflammatory disorder and uremic toxins playa major role in creating the inflammatory milieu $[1,2]$. CKD is defined by either a reduction inglomerular filtration rate (GFR) and/ or the presence of abnormalities in the urine such as protein, redblood cells or white blood cells.

Nano particles play a substantial role in one of the most promising technologies, known as nanotechnology. Nano carbon provides huge possibilities to human civilization. Activated carbons have been used since the prehistoric ageand have been playing major roles in many applications [2-4]. In the last decade, nano carbon, consisting of polymeric matrix materials and nano fillers, have held scientific, industrial and academic significance due to their improved properties. At low filler contents as compared with the conventional micro and macro or neat counterparts, theyexhibit superior property enhancements. They willconstitute $20 \%$ of demand in 2025 . Thermoplastic composites are superior to conventional microscalecomposites and can be synthesized using simpleand inexpensive techniques [4].

Nano material have huge applications in electronics, medical technology, aviation, aeronautics, polymer, engineering fields, and natural products etc. Which plays important role in our daily lifes [5].

Its well documented about the significance of Kidney organ for the survivial of human being. With the technology available for decades there is still need for developing new nano technology. In addition to the technology being somewhat stagnant over the past two and half decades, there is increasing demand for renal replacement therapy or as it's increasingly being called renal substitution therapy because none of these artificial techniques really replace kidney function entirely [34]. Itswell known that the epidemic of chronic kidney disease, which is now affecting more than 26 million people in the United States with a very high mortality from cardiovascular disease, and the continued growth of the dialysis population projected to be over 500,000 in this country just by 2010 , and we were trying to look for a way to really leapfrog from a technology point of view how patients are treated.

There are 2 general ways to produce nano-materials. The first is to start with a bulk material and then breakdownit into smaller pieces by mechanical, chemical or other form of energy -- this is termed top-down. Additional way is to synthesize the material from atomic or molecular species via chemical reactions, allowing for the precursor particles to grow in size -- this is called bottom-up. Nanotechnology, the ability to work at the atomic and molecular levels, is encouraging research and development investments in pharmaceutical discovery, diagnostics, and drug delivery and is coming to the forefront in the field of Kidney-renal substitution therapy. The novel aspect of bottom-up nanotechnology to engineer ion-selective membranes and how this aids in the management of patients with end-stage kidney-renal disease [4-6].

Since few decades, abundant nanoparticle platforms have been studied for their use in therapeutic applications. Various systems have been applied in the construction of technical systems that

Correspondence to: Ateeq Rahman, University of Namibia, Department of Chemistry and Biochemistry

Key words: Nanoparticles; kidney disease; targeting; treatment; Biotechnology

Received: January 31, 2017; Accepted: February 17, 2017; Published: February 23, 2017 
a

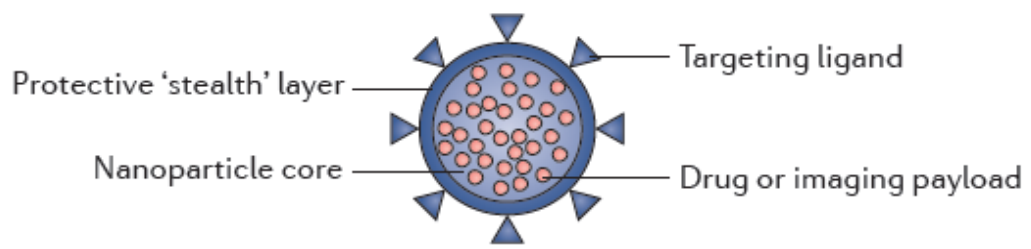

b
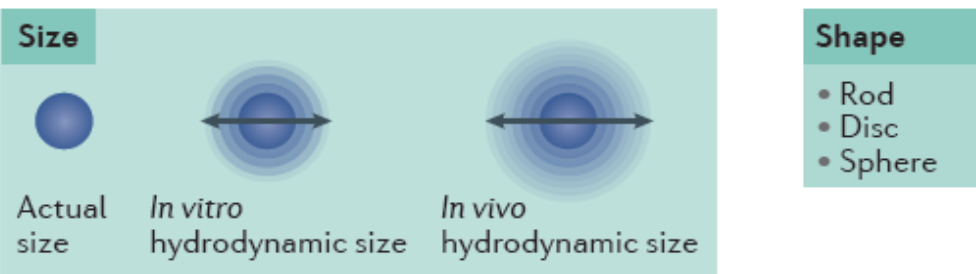

size hydrodynamic size hydrodynamic size

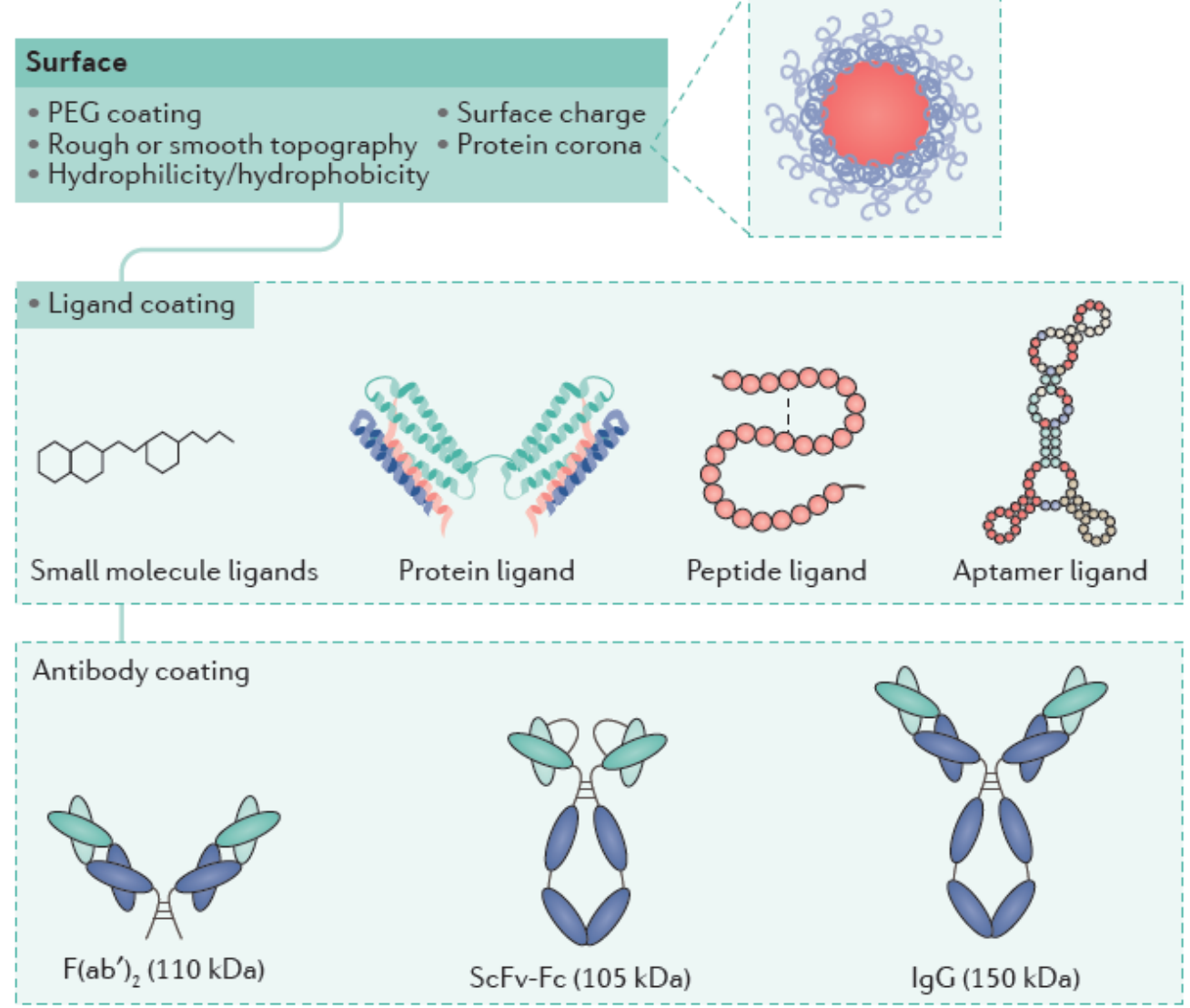

Figure 1. Nanoparticle composition and features. a. Nanoparticles are composed ofa core (payload) encapsulated in a protective layer. The surface can be modified to limitthe interactions of the particle with its environment. b. Several parameters such as size,shape and surface modification contribute to the biological and physicochemicalproperties of nanoparticles. The investigation of such properties is crucial to achieve thetranslational application of nanomedicines for kidney disease therapy. PEG, polyethyleneglycol; ScFv-Fc, single-chain variable fragment-constant fragment [8-11].

combines different functionalities which bring liposomes, polymerdrug conjugates, polymer-protein conjugates, dendrimers, polymeric micelles, polymerosomes and other nanoparticles into the realm of nanotechnology proper, as opposed to traditional pharmacology or supramolecular chemistry.Therefore, the development of polymeric nanomedicines as therapeutic agents has generated great enthusiasm both in academia and industry. The contribution of polymeric nanomedicines in the treatment of several categories of diseases including Kidney, renal,cancer, inflammatory, immunological diseases, and brain disorders is also presented [6-7].
Abundant studies in tumour therapy demonstrate that NPs can enhance drug delivery, and improve drug Cmax, pharmacokinetics and plasma area under the curve (AUC; ameasure of total drug introduction over time), comparedto the standard dose and formulation [8-11]. Hence forth, NPversus drug pharmacokinetics; encapsulated versus freecirculating drugs; drug versus NP Cmax; drug versus NPAUC; and parameters that can further affect plasma versus kidney pharmacokinetics and AUC are important. drug is generally broad and flat, whereas that of thefree drug peaks and has a tail64. These discoveries implythat NPs might reduce Cmax-associated toxicity, but 
not AUC-related toxicity, as the total dose of the drug is stillreleased by NPs, albeit at a reduced rate [11].

Nano Particle size: Nano Particle size has been broadly discovered to design effective nanomedicines. Most therapeutic NPs are 30-150 $\mathrm{nm}$ and are not subject to kidney filtration into the urine,unless they are tarnished into particles $<10 \mathrm{~nm}$, or theglomerular filtration barrier is damaged by disease (Figure 2). In healthy states, colloids and particles with a hydrodynamic diameter up to 5-7 $\mathrm{nm}$ fall below the kidney filtration threshold, pass through the glomerulus and are excreted 188 . NPs below $5.5 \mathrm{~nm}$ can be excreted via renal clearance, with an efficiency of $>50 \%$ of the injected dose $4 \mathrm{~h}$ after administration $[12,13]$.

The transport of NPs in the circulation is subjective to a greater degree by the applied convective forces in blood than by Brownian motion. Therefore, shape has animportant effect on in vivo performance and bio distribution of NPs, which exist in a wide range of geometries [14]. For example, a top-down fabrication method termed particle replication in non-wetting templates (PRINT) utilizes slithography techniques to create polymeric NPs of awide variety of geometries, shapes, and aspect ratios [15,16]. Cylindrical and discoidal shapes are uniquely subject toblood flow (they have high aspect ratios and minimal regions of curvature), which touches their interactionwith macrophages and cell membranes as particles withreduced curvature undergo faster internalization uponincubation with macrophages $[17,18]$. Similarly, nanowormornanorod (elongated cylindrical) structures showgreater tumour accumulation than other shapes [19,20].

Non-spherical NPs marginate to vessel walls more efficientlythan spherical NPs, although they are also more rapidly cleared depending on their aspect ratio anddimension [18,21-22]. In general, shapes that can sheltercellular membrane wrapping processes are optimalfor cellular internalization [23-24].

\section{Major diseases leading to Kidney failure}

There are major disease which leads to kidney failure which has

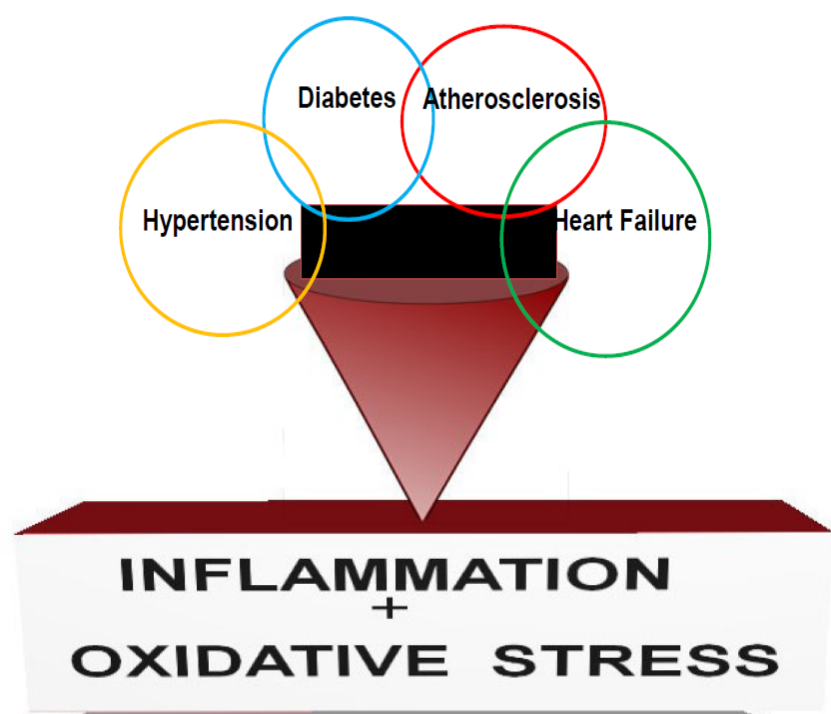

Figure 2. Hypertension, diabetes and atherosclerosis are the major disease which can leadto chronic kidney disease (CKD). Cardiovascular disease such as heart failure is the majorcause of death in patients with CKD. However, CKD can also worsen prognosis ofhypertension, diabetes, atherosclerosis and heart failure. Inappropriate inflammation andtolerance of oxidative stress plays a significant role in the development and prognosis ofthese disease processes [25]. been well studied, these are more Prevalent in developing countries, and since few decades in developed countries due to the food habits, environmental pollutions, work stress, domestic problems, financial problems and many more [25].

The majority of nano-medicines produced so far have been developed for cancer therapy, as compromised endothelial barriers in tumours facilitate NP retentionow). Over a dozen NP platforms based on liposomes [26-32], albumin [33-37], polymeric micelles [38-41], and nanosized polymer-drug conjugates [42-45] have been ratified by the FDA (Table 1). A few targeted NPs including Her2 $\mathrm{scFv}$ targeted liposomes (MM-302) [46], the first targeted controlled-release polymeric NP BIND-014 [47], and the first targeted short interfering (si) RNA NP CALAA-01 [48] are currently being tested in clinical trials for cancer therapy. Although many nano-medicines improve the pharmacokinetics and bio-distribution of drugs, so far, only one nanomedicine, CPX351, has increased survival in patients with cancer when directly matched with the conventional parent drug [49]. These findings emphasize the need to reconsider strategies for the improvement of NPs, including potential patient selection to identify those most likely to respond to nano-medicines. Nanotechnology-enabled diagnostic and therapeutics based on dendrimers [50-51], gold [52-53], silica [5455], iron oxide [53,56-57] and hafnium oxide [58-59] are also currently under clinical analysis, with the majority intended for oncological applications. For example gold NPs decorated with a surface of PEG conjugated to TNFa molecules are in phase I/II trials for solid tumour therapy [60]. Silica NPs in combination with gold are being tested in thermal ablation therapy of head and neck cancers [61]. Two MRI contrast agent iron-oxide NPs (Ferumoxtran- $10^{\circ}$ and Ferumoxytol ${ }^{\circ}$ ) are in clinical trials for cancer imaging [62-63]. A therapeutic version of iron oxide NPs termed NanoTherm ${ }^{\circledR}$ was approved in Europe in 2010 for the thermal ablation of glioblastomas (magnetic hyperthermia treatment) [64]. Clinical trials have begun for the investigation of hafnium oxide NPs (phase I), which will be used as radio-sensitizers in patients with soft-tissue sarcomas [58].

Nano-medicines are also undergoing clinical translation for gene therapy [65], RNA interference [66-68], and immunotherapy [69-70]. Viral NPs have found utility in the delivery of a range of therapeutics and have been clinically confirmed for gene therapy applications [71-73].

Kidney failure results in a build up of toxins and excess waste in the body. Dialysis is the most common treatment, performed daily either at home or in hospital. Nonetheless, dialysis machines require electricity and careful maintenance, and are therefore more readily available in developed countries than poorer nations [73]. Around one million people die each year worldwide from potentially preventable end-stage renal disease.In addition to this, in the aftermath of disasters such as the Japanese earthquakes and tsunami of 2011, dialysis patients are frequently left without treatment until normal hospital services are resumed. With this in mind, Mitsuhiro Ebara and co-workers at the International Center for Materials Nanoarchitectonics, National Institute for Materials Science in Ibaraki, Japan, have developed a way of removing toxins and waste from blood using a cheap, easyto-produce nano-fiber mesh. The mesh could be incorporated into a blood purification product small enough to be worn on a patient's arm, reducing the need for expensive, time-consuming dialysis [74].

A blood-compatible primary matrix polymer made from polyethylene-co-vinyl alcohol, or EVOH, and several different forms of zeolites - naturally occurring aluminosilicates. Zeolites have 
Table 1. Clinical use of nanoparticle [14-24].

\begin{tabular}{|c|c|c|c|c|c|c|}
\hline Nanoplatform & Composition & Size & $\begin{array}{l}\text { Examples of } \\
\text { nanoparticles } \\
\text { applied to the clinic }\end{array}$ & Disease indication & $\begin{array}{l}\text { Active } \\
\text { pharmaceutical } \\
\text { ingredient }\end{array}$ & $\begin{array}{l}\text { Clinical } \\
\text { status in } \\
2016\end{array}$ \\
\hline $\begin{array}{l}\text { Hafnium } \\
\text { oxide-based }\end{array}$ & $\mathrm{HfO}_{2} \mathrm{NPs}$ & $\sim 50 \mathrm{~nm}$ & $\begin{array}{l}\text { Non-targeted: } \\
\text { NBTXR3 }\end{array}$ & $\begin{array}{l}\text { Adult soft tissue } \\
\text { sarcoma, head and } \\
\text { neck cancer }\end{array}$ & NA (Radiotherapy) & Phase I \\
\hline $\begin{array}{l}\text { Viral } \\
\end{array}$ & $\begin{array}{l}\text { Viral and virus-like } \\
\text { nanoparticles }\end{array}$ & $20-50 \mathrm{~nm}$ & $\begin{array}{l}\text { Non-targeted: } \\
\text { Oncolytic poxvirus } \\
\text { JX-594 }\end{array}$ & $\begin{array}{l}\text { Stimulation of } \\
\text { anti-tumour immune } \\
\text { response }\end{array}$ & $\begin{array}{l}\text { Granulocyte } \\
\text { colony-stimulating } \\
\text { factor }\end{array}$ & $\begin{array}{l}\text { Phase I, } \\
\text { Phase II }\end{array}$ \\
\hline Exosomes & $\begin{array}{l}\text { Naturally secreted } \\
\text { cell-derived vesicles }\end{array}$ & $30-100 \mathrm{~nm}$ & $\begin{array}{l}\text { Targeted or } \\
\text { non-targeted: various } \\
\text { biologically derived } \\
\text { nanosized exosomes }\end{array}$ & $\begin{array}{l}\text { Immunotherapy of } \\
\text { melanoma, colon } \\
\text { cancer, diabetes, } \\
\text { wound-healing, oral } \\
\text { mucositis, gastric } \\
\text { cancer (biomarker), } \\
\text { oropharyngeal } \\
\text { cancer (biomarker), } \\
\text { thyroid cancer } \\
\text { (biomarker) }\end{array}$ & $\begin{array}{l}\text { Various biological } \\
\text { payloads }\end{array}$ & $\begin{array}{l}\text { Phase 0, } \\
\text { Phase I, } \\
\text { Phase II }\end{array}$ \\
\hline $\begin{array}{l}\text { Carbon-based } \\
\\
\end{array}$ & $\begin{array}{l}\text { Polycyclic aromatic } \\
\text { hydrocarbons }\end{array}$ & $>1 \mu \mathrm{m}$ & $\begin{array}{l}\text { Targeted or } \\
\text { non-targeted: } \\
\text { Nanospheres, } \\
\text { nanotubes, } \\
\text { nanosheets }\end{array}$ & $\begin{array}{l}\text { Breast cancer, lung } \\
\text { cancer, other solid } \\
\text { tumours }\end{array}$ & $\begin{array}{l}\text { Various } \\
\text { poorly soluble } \\
\text { therapeutics } \\
\text { in high } \\
\text { concentrations }\end{array}$ & Preclinical \\
\hline
\end{tabular}

microporous structures capable of adsorbing toxins such as creatinine from blood.

The researchers generated the mesh using a versatile and costeffective process called electrospinning - using an electrical charge to draw fibers from a liquid. Ebara and his team found that the siliconaluminum ratio within the zeolites is critical to creatinine adsorption [74]. Beta type 940-HOA zeolite had the highest capacity for toxin adsorption, and shows potential for a final blood purification product. Although the new strategy is still in its early stages and not yet ready for production, Ebara and his team are confident that a product based on their nano-fiber mesh will soon be a feasible, compact and cheap alternative to dialysis for kidney failure patients across the world [75].

The newly-fabricated nano-fiber mesh for the removal of toxins from the blood, made by WPI-MANA researchers, may be incorporated into wearable blood purification systems for kidney failure patients [76].

The kidney is aoutstanding organ for targeting of NPs due to its characteristic ability to rapidly clearparticles that are smaller than $10 \mathrm{~nm}$ in diameter 12 which is discussed above. This is accounted for by the glomerular filtration unit, the basement membrane, and the interdigitating podocytes. Within the renalcorpuscle, there exists a fenestrated endothelium separating the mesangium from the extracellular matrix. Therefore, $2 \mathrm{~nm}$ particles are readily cleared by the kidney, but significantly decreased when size is $6 \mathrm{~nm}$ and virtually no renal excretion at 11 nmdiameter [74].
Choi et al. [12-13], devised gold-loaded nanoparticles of serial core diameters entrapped by PEGpolymer of various sizes 12 . They demonstrated that NPs of $80-100 \mathrm{~nm}$ target the mesangium of the kidney, where smaller particles are seen only in the peritubular capillariesand the largest particles are taken up by the Kupffer cells in the RES of the liver and spleen.

Choi et al. [12-13] have synthesized pores for in vitro testing; they reported the fabrication of membrane with the pores in it; and we're in the process of working on the scale of methodology to produce a device. One way is the ability to miniaturize the components of the device including the membranes which permits itto be wearable and eventually implantable so that it will be transparent to the patient. Using a nano thickness $G$ membrane, it will eliminate the blood pump and run off the patient's own blood pressure [75-76].

It can be nano-manufactured the $\mathrm{G}$ membrane and engineer it in a way to make it completely biocompatible so the interaction of blood with this membrane will be such that author hope to obviate the need for anticoagulation and also eradicate membrane-induced inflammation. In addition, by using this very open $G$ membrane, it should be able to remove all of the important uremic toxins without regard to molecular weight at least up to the molecular weight of albumin [76].

It can be manufacture using nanotechnology the $\mathrm{T}$ membrane to make sure we reabsorb necessary substances and if we start seeing depletion syndromes, we can reengineer the pores to eliminate that problem [77-79]. 
It is hopefully can produce about $60 \mathrm{cc}$ a minute of glomerular filtration, which would restore patients up to early stage 3 chronic kidney disease and hopefully this would be a cost-saving approach. Still it has to be demonstrated that the membrane functions in vitro the way we modeled it on a computer. Then finally if it is a successful, it has the potential for being truely transformational or disruptive technology because it will permit patients to move out of the dialysis center into an ambulatory or home setting and that's something that we need to consider as well [78].

\section{Conclusions}

This mini review highlights about application of Nano particle in the treatment of Kidney disease. NPs have unique sizes everything in linking nanotechnology together with biotechnology. NPS size, shape structure play key role in curing kidney disease when compared dialysis which takes more time, and its not guaranteed whether the disease is cured, in order to replace this techniques NP's will play greater role in the treatment of Kidney disease. To a large scope biotechnology relies greatly on biomolecules such as proteins and DNA. Research in the field of neuroscience will definitely benefit with the advent of chemical and materials synthesis (e.g. multifunctional nanoparticle systems) that allows incorporation of these biomolecules to nanostructured inorganic and organic materials. In conclusion as the field of nanomedicine rapidly expands, with several NPs already marketed and many undergoing clinical trials, our accumulated experience and the clinical successes to date form a framework for the creation of a simple technology to irradicate this dreadful disease by utilizing NP's the next generation of Kidney nanomedicines.

\section{References}

1. Himmelfarb J, Stenvinkel P, Ikizler TA, Hakim RM (2002) The elephant in uremia: oxidant stress as a unifying concept of cardiovascular disease in uremia. Kidney Int 62: 1524-1538.[crossref]

2. Moradi H, Sica DA, Kalantar-Zadeh K (2013) Cardiovascular burden associated with uremic toxins in patients with chronic kidney disease. Am J Nephrol 38: 136-148. [crossref]

3. Lozano R, Naghavi M, Foreman K, Lim S, Shibuya K, et al. (2012) Global and regional mortality from 235 causes of death for 20 age groups in 1990 and 2010: a systematic analysis for the Global Burden of Disease Study 2010. Lancet 380: 20952128. [crossref]

4. Jha V, Garcia-Garcia G, Iseki K, Li Z, Naicker S, et al. (2013) Chronic kidney disease: global dimension and perspectives. Lancet 382: 260-272.[crossref]

5. AteeqRahman, ilias Ali, Saeed m-Al Zahrani, Rabeh H. Eleithy (2011). A review of the applications of Nano Carbon Polymer Composites. NANO: Brief Reports and Reviews. 3 185-203.

6. Polymeric Nanomedicines by Marcel Popa ,Constantin V. Uglea DOI: 10.2174/97816080548481130101 eISBN: 978-1-60805-484-8, 2013 ISBN: 978-160805-628-6.

7. Suh WH, Suslick KS, Stucky GD, Suh YH (2009) Nanotechnology, nanotoxicology, and neuroscience. Prog Neurobiol 87: 133-170.[crossref]

8. Kalra AV, Kim J, Klinz SG, Paz N, Cain J, et al. (2014) Preclinical activity of nanoliposomalirinotecan is governed by tumor deposition and intratumorprodrug conversion. Cancer Res 74: 7003-7013.[crossref]

9. Koizumi F, Kitagawa M, Negishi T, Onda T, Matsumoto S, et al. (2006) Novel SN38 -incorporating polymeric micelles, NK012, eradicate vascular endothelial growth factor-secreting bulky tumors. Cancer Res 66: 10048-10056.[crossref]

10. Nakajima TE1, Yanagihara K, Takigahira M, Yasunaga M, Kato K, et al. (2008) Antitumor effect of SN-38-releasing polymeric micelles, NK012, on spontaneous peritoneal metastases from orthotopic gastric cancer in mice compared with irinotecan. Cancer Res 68: 9318-9322.[crossref]

11. Hamaguchi T, Matsumura Y, Suzuki M, Shimizu K, Goda R, et al. (2005) NK105, a paclitaxel-incorporating micellar nanoparticle formulation, can extend in vivo antitumour activity and reduce the neurotoxicity of paclitaxel. Br J Cancer 92: 12401246. [crossref]

12. Choi HS, Liu W, Liu F, Nasr K, Misra P, et al. (2010) Design considerations for tumourtargeted nanoparticles. Nat Nanotechnol 5: 42-47. [crossref]

13. Choi HS, Liu W, Misra P, Tanaka E, Zimmer JP, et al. (2007) Renal clearance of quantum dots. Nat Biotechnol 25: 1165-1170. [crossref]

14. Toy R, Peiris PM, Ghaghada KB, Karathanasis E (2014) Shaping cancer nanomedicine: the effect of particle shape on the in vivo journey of nanoparticles. Nanomedicine (Lond) 9: 121-134.[crossref]

15. Rolland JP, Maynor BW, Euliss LE, Exner AE, Denison GM, et al. (2005) Direct fabrication and harvesting of monodisperse, shape-specific nanobiomaterials. $\mathrm{J} \mathrm{Am}$ Chem Soc 127: 10096-10100.[crossref]

16. Xu J, Wong DH, Byrne JD, Chen K, Bowerman C, et al. (2013) Future of the particle replication in nonwetting templates (PRINT) technology. AngewChemInt Ed Engl 52 6580-6589. [crossref]

17. Blanco E, Shen H, Ferrari M (2015) Principles of nanoparticle design for overcoming biological barriers to drug delivery. Nat Biotechnol 33: 941-951.[crossref]

18. Champion JA1, Mitragotri S (2006) Role of target geometry in phagocytosis. Proc Natl Acad Sci U S A 103: 4930-4934.[crossref]

19. Park JH, von Maltzahn G, Zhang L, Schwartz MP, Ruoslahti E, et al. (2008) Magnetic Iron Oxide Nanoworms for Tumor Targeting and Imaging. Adv Mater 20: 1630-1635. [crossref]

20. Chauhan VP, PopoviÄł Z, Chen O, Cui J, Fukumura D, et al. (2011) Fluorescent nanorods and nanospheres for real-time in vivo probing of nanoparticle shapedependent tumor penetration. Angew Chem Int Ed Engl 50: 11417-11420.[crossref]

21. Gentile F, Chiappini C, Fine D, Bhavane RC, Peluccio MS, et al. (2008) The effect of shape on the margination dynamics of non-neutrally buoyant particles in twodimensional shear flows. J Biomech 41: 2312-2318. [crossref]

22. Ruggiero A, Villa CH, Bander E, Rey DA, Bergkvist M, et al. (2010) Paradoxica glomerular filtration of carbon nanotubes. Proc Natl Acad Sci U S A 107: 12369-12374. [crossref]

23. Champion JA, Katare YK, Mitragotri S (2007) Particle shape: a new design parameter for micro- and nanoscale drug delivery carriers. J Control Release 121: 3-9. [crossref]

24. Petros RA, DeSimone JM (2010) Strategies in the design of nanoparticles for therapeutic applications. Nat Rev Drug Discov 9: 615-627.[crossref]

25. Ghosh SS, Gehr TW, Ghosh S3 (2014) Curcumin and chronic kidney disease (CKD): major mode of action through stimulating endogenous intestinal alkaline phosphatase. Molecules 19: 20139-20156.[crossref]

26. Lyseng-Williamson KA, Duggan ST, Keating GM (2013) Pegylated liposomal doxorubicin: a guide to its use in various malignancies. Bio Drugs 27: 533-540. [crossref]

27. Barenholz Y (2012) Doxil ${ }^{\circledR}-$-the first FDA-approved nano-drug: lessons learned. $J$ Control Release 160: 117-134.[crossref]

28. Harrison M, Tomlinson D, Stewart S (1995) Liposomal-entrapped doxorubicin: an active agent in AIDS-related Kaposi's sarcoma. J Clin Oncol 13: 914-920.[crossref]

29. Money-Kyrle JF, Bates F, Ready J, Gazzard BG, Phillips RH, et al. (1993) Liposomal daunorubicin in advanced Kaposi's sarcoma: a phase II study. ClinOncol (R CollRadiol) 5: 367-371.[crossref]

30. Rosenthal E, Poizot-Martin I, Saint-Marc T, Spano JP, Cacoub P; DNX Study Group (2002) Phase IV study of liposomal daunorubicin (DaunoXome) in AIDS-related Kaposi sarcoma. Am J Clin Oncol 25: 57-59.[crossref]

31. Meyerhoff A (1999) U.S. Food and Drug Administration approval of AmBisome (liposomal amphotericin B) for treatment of visceral leishmaniasis. Clin Infect Dis 28 42-48. [crossref]

32. Khemapech N, Oranratanaphan S, Termrungruanglert W, Lertkhachonsuk R, Vasurattana A (2013) Salvage chemotherapy in recurrent platinum-resistant or refractory epithelial ovarian cancer with Carboplatin and distearoylphosphatidylcholinepegylated liposomal Doxorubicin (lipo-dox ${ }^{\circledR}$ ). Asian Pac J Cancer Prev 14: 2131-2135.[crossref]

33. Kratz F (2008) Albumin as a drug carrier: design of prodrugs, drug conjugates and nanoparticles. J Control Release 132: 171-183.[crossref]

34. Singla AK, Garg A, Aggarwal D (2002) Paclitaxel and its formulations. Int J Pharm 235: 179-192.[crossref]

35. Kundranda MN, Niu J (2015) Albumin-bound paclitaxel in solid tumors: clinical 
development and future directions. Drug Des Devel Ther 9: 3767-3777.[crossref]

36. Liu Z, Chen X (2016) Simple bioconjugate chemistry serves great clinical advances: albumin as a versatile platform for diagnosis and precision therapy. Chem Soc Rev 45: 1432-1456.[crossref]

37. Ibrahim NK, Samuels B, Page R, Doval D, Patel KM, et al. (2005) Multicenter phase II trial of ABI-007, an albumin-bound paclitaxel, in women with metastatic breast cancer. J Clin Oncol 23: 6019-6026.[crossref]

38. Park SR, Oh DY, Kim DW, Kim TY, Heo DS, et al. (2004) A multi-center, late phase II clinical trial of Genexol (paclitaxel) and cisplatin for patients with advanced gastric cancer. Oncol Rep 12: 1059-1064.[crossref]

39. Kim TY, Kim DW, Chung JY, Shin SG, Kim SC, et al. (2004) Phase I and pharmacokinetic study of Genexol-PM, a cremophor-free, polymeric micelle-formulated paclitaxel, in patients with advanced malignancies. Clin Cancer Res 10: 3708-3716.[crossref]

40. Ediriwickrema A, Zhou J, Deng Y, Saltzman WM (2014) Multi-layered nanoparticles for combination gene and drug delivery to tumors. Biomaterials 35: 9343-9354. [crossref]

41. Talelli M, Barz M, Rijcken CJ, Kiessling F, Hennink WE, et al. (2015) CoreCrosslinked Polymeric Micelles: Principles, Preparation, Biomedical Applications and Clinical Translation. Nano Today 10: 93-117.[crossref]

42. Maeda H, Bharate GY, Daruwalla J (2009) Polymeric drugs for efficient tumor-targeted drug delivery based on EPR-effect. Eur J Pharm Biopharm 71: 409-419.[crossref]

43. Oldham EA, Li C, Ke S, Wallace S, Huang P (2000) Comparison of action of paclitaxel and poly(L-glutamic acid)-paclitaxel conjugate in human breast cancer cells. Int $J$ Oncol 16: 125-132.[crossref]

44. Duncan R (2014) Polymer therapeutics: Top 10 selling pharmaceuticals - what next? J Control Release 190: 371-380.[crossref]

45. Duncan R (2006) Polymer conjugates as anticancer nanomedicines. Nat Rev Cancer 6: 688-701.[crossref]

46. Espelin CW, Leonard SC, Geretti E, Wickham TJ, Hendriks BS (2016) Dual HER2 Targeting with Trastuzumab and Liposomal-Encapsulated Doxorubicin (MM-302) Demonstrates Synergistic Antitumor Activity in Breast and Gastric Cancer. Cancer Res 76: 1517-1527.[crossref]

47. Hrkach J, Von Hoff D, Mukkaram Ali M, Andrianova E, Auer J, et al. (2012) Preclinical development and clinical translation of a PSMA-targeted docetaxel nanoparticle with a differentiated pharmacological profile. Sci Transl Med 4: 128ra39.[crossref]

48. Davis ME, Zuckerman JE, Choi CH, Seligson D, Tolcher A, et al. (2010) Evidence of RNAi in humans from systemically administered siRNA via targeted nanoparticles. Nature 464: 1067-1070.[crossref]

49. Lancet JE (2016) Final results of a phase III randomized trial of CPX-351 versus $7+3$ in older patients with newly diagnosed high risk (secondary) AML. J. Clin. Oncol $34: 7000$

50. Kannan RM, Nance E, Kannan S, Tomalia DA (2014) Emerging concepts in dendrimerbased nanomedicine: from design principles to clinical applications. J Intern Med 276: 579-617.[crossref]

51. Roy U, Rodríguez J, Barber P, das Neves J, et al. (2015) The potential of HIV-1 nanotherapeutics: from in vitro studies to clinical trials. Nanomedicine (Lond) 10: 3597-3609. [crossref]

52. Dreaden EC, Mackey MA, Huang X, Kang B, El-Sayed MA (2011) Beating cancer in multiple ways using nanogold. ChemSoc Rev 40: 3391-3404.[crossref]

53. Anselmo AC, Mitragotri S (2015) A Review of Clinical Translation of Inorganic Nanoparticles. AAPS J 17: 1041-1054.[crossref]

54. Paithankar D, Hwang BH, Munavalli G, Kauvar A, Lloyd J, et al. (2015) Ultrasonic delivery of silica-gold nanoshells for photothermolysis of sebaceous glands in humans: Nanotechnology from the bench to clinic. J Control Release 206: 30-36.[crossref]

55. Yang Y, Yu C (2016) Advances in silica based nanoparticles for targeted cancer therapy. Nanomedicine 12: 317-332.[crossref]

56. Laurent S, Forge D, Port M, Roch A, Robic C, et al. (2008) Magnetic iron oxide nanoparticles: synthesis, stabilization, vectorization, physicochemical characterizations, and biological applications. Chem Rev 108: 2064-2110.[crossref]

57. Maier-Hauff K, Ulrich F, Nestler D, Niehoff H, Wust P, et al. (2011) Efficacy and safety of intratumoral thermotherapy using magnetic iron-oxide nanoparticles combined with external beam radiotherapy on patients with recurrent glioblastomamultiforme. $J$ Neurooncol 103: 317-324.[crossref]
58. Maggiorella L, Barouch G, Devaux C, Pottier A, Deutsch E, et al. (2012) Nanoscale radiotherapy with hafnium oxide nanoparticles. Future Oncol 8: 1167-1181.[crossref]

59. Field JA, Luna-Velasco A, Boitano SA, Shadman F, Ratner BD, et al. (2011) Cytotoxicity and physicochemical properties of hafnium oxide nanoparticles. Chemosphere 84 : 1401-1407. [crossref]

60. Libutti SK, Paciotti GF, Byrnes AA, Alexander HR Jr, Gannon WE, et al. (2010) Phase I and pharmacokinetic studies of CYT-6091, a novel PEGylated colloidal goldrhTNFnanomedicine. Clin Cancer Res 16: 6139-6149.[crossref]

61. Li J, Gupta S, Li C (2013) Research perspectives: gold nanoparticles in cancer theranostics. Quant Imaging Med Surg 3: 284-291.[crossref]

62. Fortuin AS, Meijer H, Thompson LC, Witjes JA, Barentsz JO (2013) Ferumoxtran-10 ultrasmallsuperparamagnetic iron oxide-enhanced diffusion-weighted imaging magnetic resonance imaging for detection of metastases in normal-sized lymph nodes in patients with bladder and prostate cancer: do we enter the era after extended pelvic lymph node dissection? Eur Urol 64: 961-963.[crossref]

63. Hedgire SS, Mino-Kenudson M, Elmi A, Thayer S, Fernandez-del Castillo C, et al. (2014) Enhanced primary tumor delineation in pancreatic adenocarcinoma using ultrasmall super paramagnetic iron oxide nanoparticle-ferumoxytol: an initial experience with histopathologic correlation. Int J Nanomedicine 9: 1891-1896. [crossref]

64. Rivera Gil P, Hühn D, del Mercato LL, Sasse D, Parak WJ (2010) Nanopharmacy: Inorganic nanoscale devices as vectors and active compounds. Pharmacol Res 62: 115125. [crossref]

65. TolcherAW, Rodrigueza WV, Rasco DW, Patnaik A, Papadopoulos KP, et al. (2014) A phase 1 study of the BCL2-targeted deoxyribonucleic acid inhibitor (DNAi) PNT2258 in patients with advanced solid tumors. Cancer Chemother Pharmacol 73: 363-371. [crossref]

66. Schultheis B, Strumberg D, Santel A, Vank C, Gebhardt F, et al. (2014) First-in-human phase I study of the liposomal RNA interference therapeutic Atu027 in patients with advanced solid tumors. J Clin Oncol 32: 4141-4148. [crossref]

67. Jensen SA, Day ES, Ko CH, Hurley LA, Luciano JP, et al. (2013) Spherical nucleic acid nanoparticle conjugates as an RNAi-based therapy for glioblastoma. Sci Transl Med 5: 209ra152.[crossref]

68. Islam MA, Reesor EK, Xu Y, Zope HR, Zetter BR, et al. (2015) Biomaterials for mRNA delivery. BiomaterSci 3: 1519-1533.[crossref]

69. Park J, Wrzesinski SH, Stern E, Look M, Criscione J, et al. (2012) Combination delivery of TGF- $\hat{I}^{2}$ inhibitor and IL-2 by nanoscale liposomal polymeric gels enhances tumour immunotherapy. Nat Mater 11: 895-905.[crossref]

70. Lee IH, An S, Yu MK, Kwon HK, Im SH, et al. (2011) Targeted chemoimmunotherapy using drug-loaded aptamer-dendrimerbioconjugates. J Control Release 155: 435-441. [crossref]

71. Park BH, Hwang T, Liu TC, Sze DY, Kim JS, et al. (2008) Use of a targeted oncolytic poxvirus, JX-594, in patients with refractory primary or metastatic liver cancer: a phase I trial. Lancet Oncol 9: 533-542.[crossref]

72. Yildiz I, Shukla S, Steinmetz NF (2011) Applications of viral nanoparticles in medicine. Curr Opin Biotechnol 22: 901-908. [crossref]

73. Czapar AE, Zheng YR, Riddell IA, Shukla S, Awuah SG1, et al. (2016) Tobacco Mosaic Virus Delivery of Phenanthriplatin for Cancer therapy. ACS Nano 10: 4119-4126. [crossref]

74. Kamaly N, He JC, Ausiello DA, et al. (2016) Nanomedicines for renal disease: current status and future applications. Nat Rev Nephrol 12: 738-753.[crossref]

75. Farokhzad OC, Langer R (2009) Impact of nanotechnology on drug delivery. ACS Nano 3: 16-20.[crossref]

76. Choi CH, Zuckerman JE, Webster P, Davis ME (2011) Targeting kidney mesangium by nanoparticles of defined size. Proc Natl Acad Sci U S A108: 6656-6661.[crossref]

77. Koki Namekawa, Makoto Tokoro Schreiber, Takao Aoyagia, Mitsuhiro Ebara (2014) Fabrication of zeolite-polymer composite nano-fibers for removal of uremic toxins from kidney failure patients. Biomaterials Science 2: 674-679.

78. Etika KC, Liu L, Hess LA, Grunlan JC (2009) Carbon 47: 3128.

79. Zhang W, Dehghani-Sanij AA, Blackburn RS, Mater J (2007). Sci 42: 3408

Copyright: (C)2017 Rahman A. This is an open-access article distributed under the terms of the Creative Commons Attribution License, which permits unrestricted use, distribution, and reproduction in any medium, provided the original author and source are credited. 